\title{
Effects of sacred music on the spiritual well-being of bereaved relatives: a randomized clinical trial*
}

\author{
Efeitos da música sacra no bem-estar espiritual de familiares \\ enlutados: ensaio clínico randomizado \\ Efectos de la música sacra en el bienestar espiritual de \\ familiares enlutados: ensayo clínico randomizado
}

\author{
Vladimir Araujo da Silva ${ }^{1}$ Rita de Cássia Frederico Silva², Nubia Carla Ferreira Cabau², Eliseth Ribeiro Leão ${ }^{3}$, Maria Júlia \\ Paes da Silva ${ }^{4}$
}

How to cite this article:

Silva VA, Silva RCF, Cabau NCF, Leão ER, Silva MJP. Effects of sacred music on the spiritual well-being of bereaved relatives: a randomized clinical trial. Rev Esc Enferm USP. 2017;51:e03259. DOI: http://dx.doi.org/10.1590/S1980-220X2016009903259

\footnotetext{
* Extracted from the thesis "Bem-estar espiritual decorrente da audição passiva de música sacra em familiares enlutados: ensaio clínico randomizado”, Programa de Pós-Graduação em Enfermagem na Saúde do Adulto, Escola de Enfermagem, Universidade de São Paulo, 2015.

${ }^{1}$ Faculdade de Apucarana, Apucarana, PR, Brazil.

${ }^{2}$ Associação de Pais e Amigos dos Excepcionais, Astorga, PR, Brazil.

${ }^{3}$ Hospital Israelita Albert Einstein, Instituto de Ensino e Pesquisa, São Paulo, SP, Brazil.

${ }^{4}$ Universidade de São Paulo, Escola de Enfermagem, São Paulo, SP, Brazil.
}

\begin{abstract}
Objective: To evaluate the effects of instrumental sacred music and sacred music with vocals on the spiritual well-being of bereaved relatives. Method: This is a randomized clinical trial carried out with family members bereaving the death of loved ones to cancer. Participants were allocated into three groups: Group 1 (control), Group 2 (experimental using sacred music with vocals) or Group 3 (experimental using instrumental sacred music). Spiritual well-being was assessed through the Spiritual Well-Being Scale. Results: Sixty-nine (69) family members participated. Mean scores before and after the intervention indicated high levels of spiritual well-being (106.4 and 105.5 in Group 1; 103.2 and 105.2 in Group 2; 107.4 and 108.7 in Group 3) and religious well-being (57.9 and 56.9 in Group 1; 56.3 and 56.4 in Group 2; 57.4 and 58.1 in Group 3), and moderate levels of existential well-being (48.5 and 48.6 in Group 1; 46.9 and 48.9 in Group 2; 49.9 and 50.7 in Group 3), with the exception of Group 3 which presented a high level of existential well-being after the intervention. Conclusion: The results show that there were no statistically significant differences in the spiritual well-being scores between the experimental groups and the control group. We evidence the need for further studies that use music therapy as a Nursing intervention for bereaved families. Brazilian Registry of Clinical Trials: RBR-2wtwjz.
\end{abstract}

DESCRIPTORS

Death; Grief; Music; Music Therapy; Spirituality; Holistic Nursing. 


\section{INTRODUCTION}

Bereavement is a natural and expected reaction to the rupture of a bond; a dynamic, subjective and multidimensional process of elaborating a significant loss, permeated by intense emotional suffering ${ }^{(1)}$. Nevertheless, the absence of empathy, social support and religious or social rituals tend to intensify the emotional reactions, making the mourning process more difficult. On the other hand, interactional practices can contribute to constructing meanings and elaborating the grieving process of relatives $^{(2)}$, conferring oneness, dynamicity and subjectivity to their spirituality ${ }^{(3)}$.

We emphasize that spiritual well-being refers to the human being's subjective perception of their well-being in relation to his or her belief, and it constitutes one of the aspects of spirituality that can be evaluated ${ }^{(4)}$. In fact, spirituality and religiosity support coping with adversities and stressful and traumatic events ${ }^{(5)}$, helping give meaning to the experiences of death, as well as providing social, emotional and spiritual support that renews energy and directs the behavior of relatives during their state of adapting to death ${ }^{(6)}$. Nevertheless, there are still gaps concerning the "understanding of what spiritual distress is, the role of spirituality/ religiosity in situations of mourning and death, as well as the strategies for alleviating spiritual suffering, improving acceptance and communication" ${ }^{\prime \prime}$.

Concerning sacred music, they are compositions constituted of a certain holiness, destined for liturgical celebration and the cult of $\mathrm{God}^{(8)}$, with lyrics, style and form that align with implicit affective records, and act as a potent catalyst for spiritual experiences. Its evocative potential can transport listeners to inaccessible dimensions of the psyche ${ }^{(9-10)}$.

We emphasize that the qualities of sacred music derive from its ability to transform the listener's temporal perception, producing a sense of timelessness in which music subsidizes an encounter between mind and infinity ${ }^{(10)}$. In this context, we can highlight the study conducted by Brazilian nurses, which aimed to verify the effects of the Gregorian Chant on the anxiety state of mothers of hospitalized children. The results show that the use of the Gregorian Chant reduced mothers' anxiety state ${ }^{(11)}$.

Given the above, and due to the scarcity of studies that evaluate the effects of music therapy as a Nursing intervention to bereaved families, and specifically using sacred music, the present study aimed to evaluate the effects of instrumental sacred music and sacred music with vocals on the spiritual well-being of bereaved relatives. We believed that bereaved family members who listen to sacred music have better levels of spiritual well-being than bereaved family members who do not, and that sacred music with vocals supports better levels of spiritual well-being in relation to instrumental sacred music.

The relevance of the present study is justified as it highlights the need for care of family members coping with suffering inherent in the loss of a loved one and in the process of mourning.

\section{METHOD}

This is a randomized parallel clinical trial, approved by the Ethics and Research Committee of the School of Nursing of the University of São Paulo, Opinion 489.976, of 2013, and published in the Brazilian Registry of Clinical Trials (ReBEC): RBR-2wtwjz. We emphasize that the sample calculation was performed when the number of 30 participants was reached, so that the observed difference was significant $(n=69)$, with $95 \%$ confidence and power, assuming that the effect size remained or was greater, and determined the end of data collection.

Among the eligibility criteria for the participants, the following inclusion criteria were adopted: those grieving the death of a loved one (father, mother or spouse) and enrolled in the Maringá-PR Women's Network to Combat Cancer (RFCC) (a not-for-profit philanthropic entity that attends people with cancer who are in situations of social vulnerability), whose relative died from cancer, for at least 1 month and at most 12 months; having participated in the care process at the end of the life of their loved one; residing in the municipalities of Maringá-PR, Sarandi-PR or Paiçandu-PR; being aged 18 years or more; having preserved auditory function; and having preserved language function. Exclusion criteria were: family members who had moved, those with hearing or cognitive difficulty during the intervention, or those who had experienced the loss of another family member.

Data were collected between January 2014 and March 2015 , and participants were allocated by simple randomization (1:1 allocation rate) into Group 1 - control (no intervention), Group 2 - experimental (sacred music with vocals) and Group 3 - experimental (instrumental sacred music). A draw was implemented by the researcher to generate a randomized allocation sequence.

Thus, after drawing the first participant for the group (Group 1), the others were allocated following the sequence Group 2, Group 3, Group 1, successively, making it impossible to conceal the sequence until the interventions were assigned. We point out that in some cases the family was randomized due to the family dynamics, as family members met together to receive the researcher when the first visit was scheduled. In these cases, the intervention was performed in a group, however data collection was performed individually.

We consider that the absence of lyrics in instrumental songs do not characterize them as sacred, even when presenting less elaborate structures than traditional erudite music, as they contain in themselves the essence of the composition and the composer's intention, as well as the fact that the participants were aware that they would listen to instrumental sacred music. Regarding eligibility criteria (Figure 1), 33 of the 169 bereaved families assessed for eligibility did not agree to participate in the study, 59 did not meet the inclusion criteria and five dropped out before data collection due to unavailability to schedule the visits. There were also three follow-up losses for the same reason, making it impossible to complete the collection. 


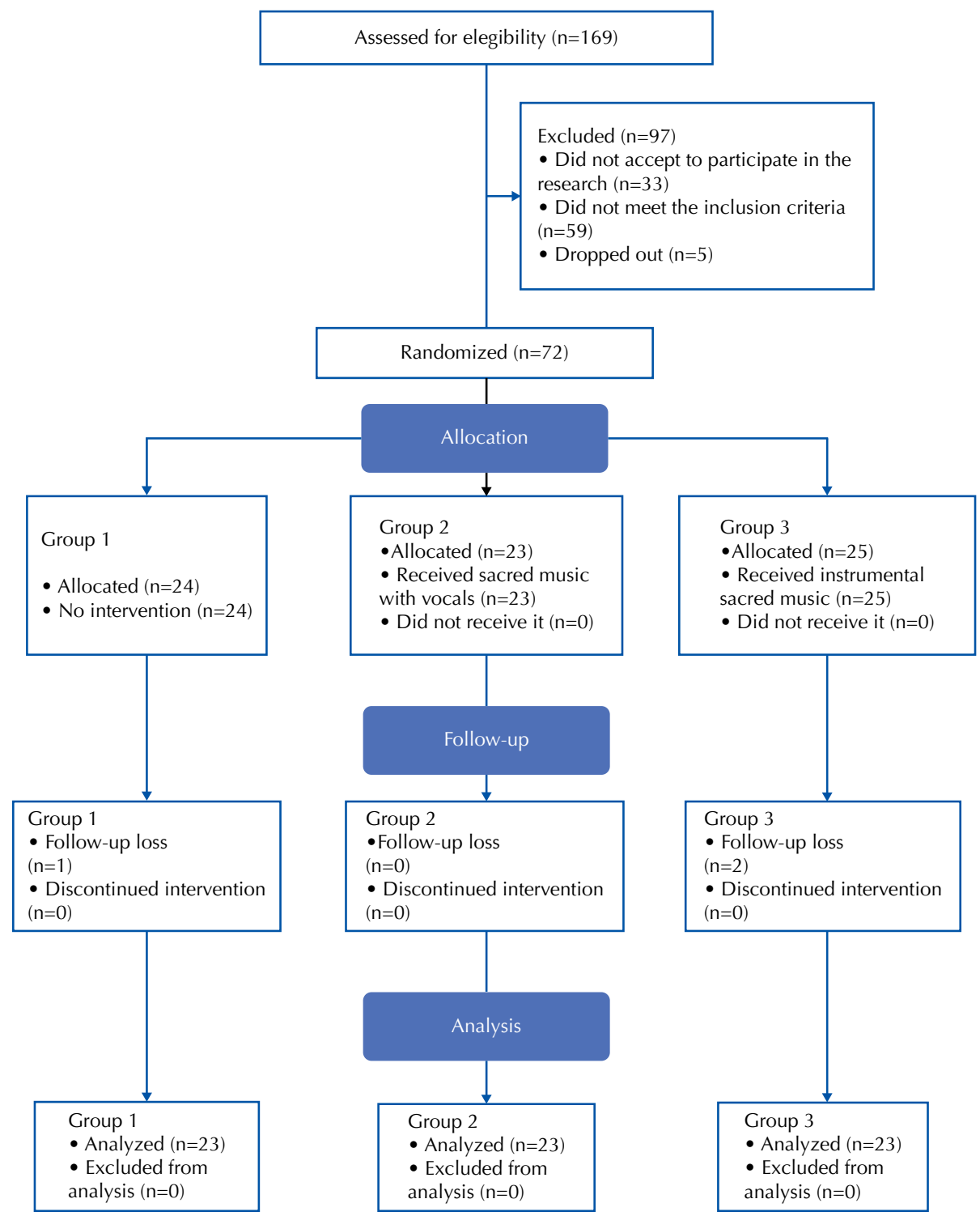

Figure 1 - Criteria for eligibility of participants - Maringá, PR, Brazil, 2015. Source: Adapted from CONSORT 2010 Flow Diagram ${ }^{(12)}$.

The psychometric instrument used to reach the study objective was the Spiritual Well-Being Scale (SWBS), adapted and validated for the Brazilian population ${ }^{(13)}$. It is worth mentioning that the SWBS was applied before and after the intervention in the experimental groups, while it was applied at two moments in the control group with an interval of 1 month without intervention. It follows a six-point Likert scale: I totally agree (TA), I agree more than I disagree (Ad), I partially agree (PA), I partially disagree (PD), I disagree more than I agree (Da), and I totally disagree (TD), composed of 20 items arranged in two subscales: Religious Well-Being $(\mathrm{RWB})$ and Existential Well-Being $(\mathrm{EWB})^{(13)}$.

RWB evaluates the vertical dimension of spirituality, which contains a reference to God and is related to satisfaction in connection with Him or with something that transcends human dimensions, and which has been positively associated with inner strength and hope, and negatively associated with depression and loneliness. EWB evaluates the horizontal dimension of spirituality, which refers to the perception in relation to the sense and meaning of life, regardless of a religious reference ${ }^{(13)}$. In order to avoid possible discomfort, the participants were instructed to replace the word "God" with any other word related to their spirituality, religiousness or religious belief before responding to the SWBS.

Items with positive connotations $(3,4,7,8,10,11,14,15$, $17,19,20)$ have their score added up as follows: $\mathrm{TA}=6, \mathrm{Ad}=5$, $\mathrm{PA}=4, \mathrm{PD}=3, \mathrm{Da}=2$ and $\mathrm{TD}=1$. The remaining items have negative connotations and should be added up in reverse: $\mathrm{TA}=1, \mathrm{Ad}=2, \mathrm{PA}=3, \mathrm{PD}=4, \mathrm{Da}=5$ and $\mathrm{TD}=6$. Suggested cutoff points for the overall score are intervals from 20 to 40 , from 41 to 99 and from 100 to 120 for low, moderate and high spiritual well-being, respectively. High scores are considered positive spiritual well-being, and low and moderate 
scores are considered negative spiritual well-being. In the two subscales, the cutoff points are 10 to 20,21 to 49 and 50 to 60 points for low, moderate and high spiritual wellbeing, respectively ${ }^{(13)}$.

In order to allow comparisons and replications of studies due to the variety and complexity of musical stimuli and other intervening factors, and especially the importance attributed to the detailed description of the musical resources, the recommended guidelines for musical intervention studies in the health area were adopted ${ }^{(14)}$. Thus, sacred music was chosen as a theoretical reference.

Regarding the intervention content, the songs were preselected by the researcher considering an analysis of the lyrics which deal with themes such as faith, hope, death and resurrection. These songs compose the album "Vida Agora e Sempre" from the label COMEP - Vossa presença faz viver, Prece ao Deus vivo; Quando a dor chegar - interpreted by Coral Imaculada Conceição, and conducted by Frei Luiz Turra. We emphasize that the structure of the songs comprises ternary, quaternary and quaternary rhythms, and tonalities of $\mathrm{D}$ major, $\mathrm{D}$ major and $\mathrm{G}$ major, respectively.

Based on the Expanded Lens Model, originated from psychology and used in understanding the processes of emotional communication in music, from the conception that composers and interpreters use musical codes known as "acoustic cues" to communicate specific emotions to the listeners ${ }^{(15)}$, the researchers have identified the following acoustic cues in the songs used in the present study: moderate tempo with little variability; greater mode with simple harmony consonant; medium intensity with little variability; medium or low frequencies (more evident in the intervention with sung music), and medium or high frequencies (more evident in the intervention with instrumental music), with little variability or moderate variability in both cases; ascending melodic contour; legato articulation with little variability; regular rhythm; soft (more evident in the intervention with sung music) or brilliant timbre (more evident in the intervention with instrumental music); quick attacks; absence of vibrato; little contrast between the duration of the notes; accentuation on harmonically stable notes.

It is emphasized that above-mentioned acoustic cues converge to describe the acoustic cues inherent to the emotions of "joy" and "serenity", described in a study that aimed to investigate the perception of emotions in Brazilian music, while minor modes are associated with the emotions "sadness", "anger" and "fear" ${ }^{(15)}$. The musical presentation method was live in pleasant volume; however decibel levels were not measured.

Regarding the intervention materials, male human voice (tenor) and acoustic guitar were used in Group 2; acoustic guitar and recorder (contralto) were used in Group 3; musical repertoire; music sheet rack, chairs or sofas. The intervention strategy was a "musical audition", outlined in four sessions of 20 minutes each once a week in the experimental groups, and only one session in the control group, if the participant expressed interest in listening to the songs after data collection.

Although it is possible to obtain significant results in a single musical session due to the extension of the mourning process, the researcher's intention was to accompany the participants for 1 month (four weeks) in an attempt to generate psychosocial-spiritual support mediated by music, which would probably not be possible to be offered in a single session. We should also point out that the researcher, nurse and musician with previous clinical experience were responsible for applying the intervention in Group 2, and there was collaboration of a flautist in Group 3 who was instructed to play the songs according to musical scores, thus minimizing possible interactions and biases in the outcomes.

Treatment reliability which guarantees control conditions was attributed to the SWBS application before and after the intervention carried out in the participants' homes - users enrolled in the RFCC of Maringá-PR - as levels of privacy and sonority varied according to the dynamics of each family and the geographic location of the residence. The target population varied according to the availability of the family members. Most of the interventions were individual, however some interventions were carried out with two (5 groups), three (3 groups), four (1 group) and seven participants (1 group). Despite this fact, the SWBS was applied individually in a reserved environment.

Descriptive and inferential statistical analyzes were carried out at a 5\% level of significance. An ANOVA model for repeated-measures was used to longitudinally compare SWBS, RWB, and EWB scores between the groups, while the chi-square test was used to compare the categorical descriptors and an ANOVA model was used for numerical variables, in addition to the interaction and intervention effect tests through the Statistical Package for the Social Sciences (SPSS) software (Version 22). It is emphasized that the interventions performed in groups were analyzed individually.

\section{RESULTS}

Data from 69 bereaved relatives were analyzed, but no statistically significant difference was found in the comparison between the groups. Participants' distribution according to the studied groups and their characterization is presented in Table 1.

Table 1 - Characterization of the participants according to the studied groups - Maringá, PR, Brazil, 2005.

\begin{tabular}{|c|c|c|c|c|c|c|c|}
\hline \multirow{2}{*}{ Variables } & \multicolumn{2}{|c|}{ Group $1(n=23)$} & \multicolumn{2}{|c|}{ Group 2 (n=23) } & \multicolumn{2}{|c|}{ Group 3 (n=23) } & \multirow{2}{*}{ p-value } \\
\hline & Mean & SD & Mean & Dp & Mean & SD & \\
\hline Age (years) & 51.8 & 14.6 & 44.7 & 10.7 & 46.9 & 12.6 & 0.155 \\
\hline Bereavement (months) & 6.0 & 3.3 & 5.6 & 3.3 & 4.1 & 3.7 & 0.162 \\
\hline
\end{tabular}




\begin{tabular}{|c|c|c|c|c|c|c|c|}
\hline \multirow{2}{*}{ Variables } & \multicolumn{2}{|c|}{ Group $1(n=23)$} & \multicolumn{2}{|c|}{ Group $2(n=23)$} & \multicolumn{2}{|c|}{ Group $3(n=23)$} & \multirow{2}{*}{ p-value } \\
\hline & Mean & SD & Mean & Dp & Mean & SD & \\
\hline & $\mathbf{N}$ & $\%$ & $\mathbf{N}$ & $\%$ & $\mathrm{~N}$ & $\%$ & \\
\hline Degree of kinship & & & & & & & 0.293 \\
\hline Spouse & 9 & 39.1 & 6 & 26.1 & 4 & 17.4 & \\
\hline Children (Son/daughter) & 14 & 60.9 & 17 & 73.9 & 19 & 82.6 & \\
\hline Religion & & & & & & & 0.027 \\
\hline Catholic & 15 & 65.2 & 15 & 65.2 & 7 & 30.4 & \\
\hline Evangelican & 8 & 34.8 & 8 & 34.8 & 16 & 69.6 & \\
\hline Importance of religion & & & & & & & 0.834 \\
\hline Little important & 1 & 4.3 & - & - & - & - & \\
\hline Relatively important & 1 & 4.3 & 2 & 8.7 & - & - & \\
\hline Important & 2 & 8.7 & 2 & 8.7 & 3 & 13.0 & \\
\hline Very important & 19 & 82.6 & 19 & 82.6 & 20 & 87.0 & \\
\hline Death process & & & & & & & 0.146 \\
\hline Short ( $\leq 6$ months) & 11 & 47.8 & 6 & 26.1 & 5 & 21.7 & \\
\hline Long (> 6 months) & 12 & 52.2 & 17 & 73.9 & 18 & 78.3 & \\
\hline Habit of listening to music & & & & & & & 0.772 \\
\hline Yes & 18 & 78.3 & 20 & 87.0 & 20 & 87.0 & \\
\hline No & 5 & 21.7 & 3 & 13.0 & 3 & 13.0 & \\
\hline
\end{tabular}

Source: Silva VA ${ }^{(16)}$.

Mean SWBS scores revealed that participants had high levels of Spiritual Well-Being (positive Spiritual WellBeing) and RWB, with moderate levels of EWB. A slight increase in the mean of the EWB scores was observed after the intervention, altering its status from moderate to high in the experimental instrumental music group, as shown in figures 2,3 and 4 .

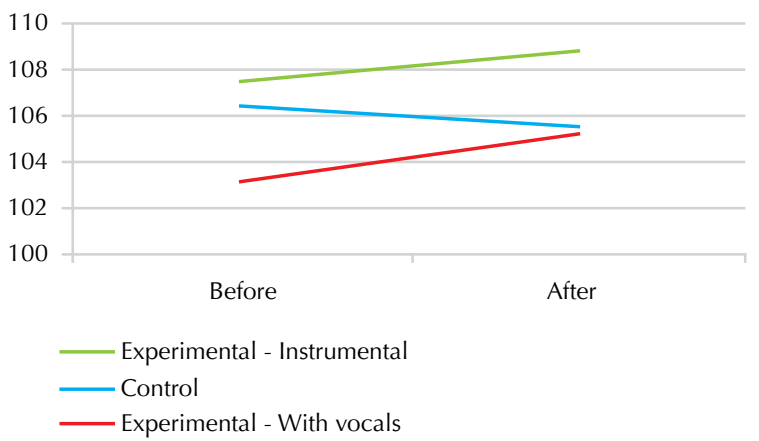

Figure 2 - Comparison between groups regarding the effects of music on Spiritual Well-being of bereaved family members Maringá, PR, Brazil, 2015. Source: Silva VA ${ }^{(16)}$.

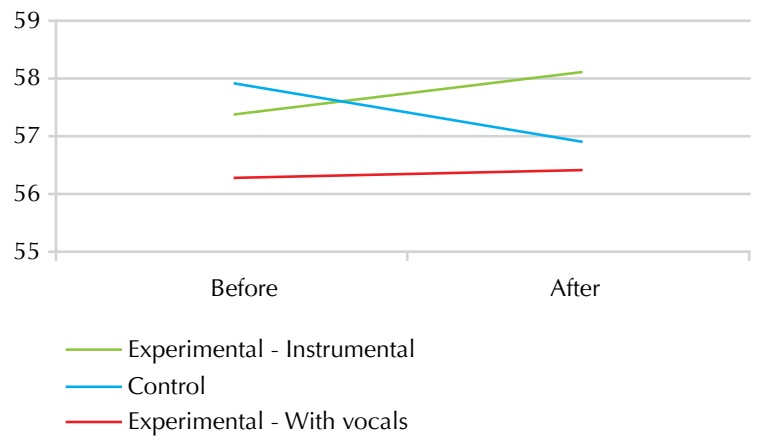

Figure 3 - Comparison between groups regarding the effects of music on Religious Well-being of bereaved family members - Maringa, PR, Brazil, 2015. Source: Silva VA ${ }^{(16)}$.

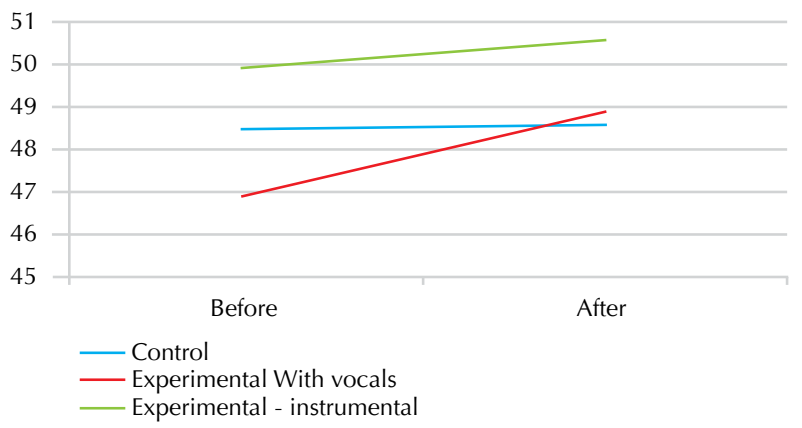

Figure 4 - Comparison between groups regarding the effects of music on the Existential Well-Being of bereaved family members - Maringá, PR, Brazil, 2015. Source: Silva VA ${ }^{(16)}$.

The interaction effect test found that the differences between the SWBS scores obtained before and after the intervention were the same for the three groups $(p=0.000)$, and the intervention effect test also found that such differences, regardless of group, were not statistically significant $(p=0.467$ for SWBS; $p=0.857$ for RWB; and $\mathrm{p}=0.313$ for EWB).

\section{DISCUSSION}

Although the results were not statistically significant, the upward trends presented in Figures 2, 3 and 4 suggest a tendency for music therapy, especially of sacred music with vocals, to improve levels of spiritual well-being in bereaved individuals. Indeed, sacred music can stimulate spiritual $^{(9)}$ and emotional experiences, influencing the minds of bereaved relatives about religious/existential issues, and consequently their levels of spiritual well-being. We emphasize that the qualities of sacred music derive from its ability to transform the listener's temporal perception, producing a sense of timelessness in which music enables an encounter between mind and infinity ${ }^{(10)}$. 
Regarding the use of music therapy as an intervention in mourning, we can point out a randomized controlled pilot study of mixed methods which aimed to evaluate the efficacy of bereavement-specific music therapy as compared to exclusive standard care in 10 adults with mental illness and in complicated suffering, using Wordmen's theories on grief therapy; music therapy based on Shear, Frank, Houck and Reynolds, and Austin's method of vocal psychotherapy. The results showed that the participants in the experimental group had a greater reduction in mourning symptoms in comparison to the control group ${ }^{(17)}$, as measured by the Inventory of Complicated Grief (ICG-R).

We can also cite a qualitative study that explored the meaning of music in pre-loss music therapy sessions with seven mourning caregivers. Although the authors did not specify the implemented musical resources, the results suggest that pre-loss music therapy may have long-lasting effects that positively affect suffering, and transforms the bereavement time. Music was referred to as a "conduit" through which people can "travel" to times and places of beauty, happiness, sense of life and inspiration, in addition to transmitting soothing vibrations and promoting expressiveness and relaxation ${ }^{(18)}$.

Another study with a phenomenological approach aimed at revealing the perception of patients and family members who experience cancer in a support home in relation to musical encounters, and concluded that music therapy inspired life to the participants' days, giving them a feeling of being cared for ${ }^{(19)}$, while it also enabled the expression of feelings, providing a moment of existential and spiritual introspection to the relatives ${ }^{(20)}$, thus attributing new meanings to their existential condition and offering coping strategies for dealing with the illness of their loved ones ${ }^{(19)}$.

According to this philosophy, listening to sacred music can contribute to the adaptation process of the loss of bereaved relatives, considering that the spiritual well-being resulting from musical encounters, especially in regard to sacred music, can represent a psycho-socio-spiritual support that provides comfort, reflection and motivation. In this context, relatives who participated in musical encounters digested music as a remedy for their suffering, feeding them spiritually, making them feel the presence of $\operatorname{God}^{(20)}$.

It is worth noting that the presence of the researcher integrated the intervention, since their interaction with the participant - exchanging looks, smiles - is an additional stimulus that can produce different effects, and is impossible to be expressed when the music is played by a stereo or headphones. On the other hand, their simple presence and the awareness that someone cared about them and made time to listen to them, according to the reflections and the statements that emerged during data collection, may have influenced perception and improvement of EWB levels among the participants of the control group. Even the presence of the flute player, and their inevitable interaction with the participants may also have influenced the results obtained in the experimental group of instrumental music. However, this variable is difficult to be controlled when live music is used.

Contextualizing it, the ideas of Martin Buber ratify the perception that interpersonal relations translate into EWB characteristics, considering that in the I/You relationship, the human being becomes involved with the other - a human being, an event, a piece or any entity - letting themselves be impacted and crossed by this living presence. At that moment, there is an intensive, immeasurable or irreducible dimension to temporality, spatiality and objectivity, which enables contemplation, new sensations and crossings; an authentic and intersubjective encounter, allowing people to be touched and transformed ${ }^{(21)}$.

With regard to spiritual/religious support, we noticed that all study participants were Christians - 37 were Catholics (53.6\%) and 32 were Evangelicans (46.4\%) - and that the majority attributed great importance to religion (84.1\%). Contextualizing, the assumption that "the meanings of death and mourning connected to religious beliefs and to spirituality can interfere in the elaboration of mourning" led to a qualitative clinical study with six elderly widows. The results emphasize that believing in God can significantly contribute to the construction of meanings related to the restoration of loss; religion can provide insight into the death of a loved one; the belief in the afterlife and the conception of death as a "divine call" can facilitate the elaboration of a loss ${ }^{(22)}$.

As limitations of the study, we can point out the following: non-prior classification of the participants in relation to the mourning stages, given that levels of spiritual well-being may vary depending on the mourning stage in which they are experiencing, and also the responses to music therapy; the method used to generate a randomized allocation sequence and non-concealment of the mechanism used to implement the allocation; the impossibility of controlling internal and external noise in the home environment; and the difficulty in establishing a homogeneous sample.

We suggest developing further studies that comprise inclusion criteria of: family members who have been in mourning for less than 1 month, those who have moderate or low levels of spiritual well-being, or the nursing diagnoses "Complicated grieving" or "Spiritual suffering", as well as their classification regarding the mourning phases which they are experiencing. In contemplating that spirituality is multidimensional and multifactorial which hampers its perception and measurement, especially quantitatively, as well as the sensitivity of SWBS to the mood of bereaved relatives and the perspective with which they perceive it, we suggest the use of mixed or qualitative methodological designs that allow access to the subjectivity inherent to music therapy and to the You/I relationship.

\section{CONCLUSION}

The results show that there were no statistically significant differences in the spiritual well-being scores between the experimental groups and the control group. However, they suggest a tendency for sacred music to improve the levels of spiritual well-being of bereaved relatives, especially sacred music with vocals. In contrast, the change of status from moderate to high found in Group 3 suggests that instrumental sacred music can improve the EWB of bereaved relatives. We highlight the need to develop further studies that use music therapy as a Nursing intervention for bereaved families. 
RESUMO

Objetivo: Avaliar os efeitos da música sacra, instrumental e cantada, no bem-estar espiritual de familiares enlutados. Método: Tratase de um ensaio clínico randomizado, realizado com familiares enlutados pela morte, por câncer, de entes queridos. Os participantes foram alocados em três grupos: Grupo 1 (controle), Grupo 2 (experimental com música sacra cantada) ou Grupo 3 (experimental com música sacra instrumental). O bem-estar espiritual foi avaliado por meio da Escala de Bem-Estar Espiritual. Resultados: Participaram 69 familiares. Os escores médios, antes e após a intervenção, indicaram altos níveis de bem-estar espiritual (106,4 e 105,5 no Grupo 1; 103,2 e 105,2 no Grupo 2; 107,4 e 108,7 no Grupo 3) e bem-estar religioso (57,9 e 56,9 no Grupo 1; 56,3 e 56,4 no Grupo 2; 57,4 e 58,1 no Grupo 3), e moderados níveis de bem-estar existencial (48,5 e 48,6 no Grupo 1; 46,9 e 48,9 no Grupo 2; 49,9 e 50,7 no Grupo 3), com exceção do Grupo 3 que, após a intervenção, apresentou alto nível. Conclusão: Os resultados demonstram que não houve diferença estatisticamente significativa nos escores de bem-estar espiritual entre os grupos experimentais e o grupo controle. Evidencia-se a necessidade de novas pesquisas que utilizem a musicoterapia como intervenção de Enfermagem à família enlutada. Registro Brasileiro de Ensaios Clínicos: RBR-2wtwjz.

\section{DESCRITORES}

Morte; Pesar; Música; Musicoterapia; Espiritualidade; Enfermagem Holística.

\section{RESUMEN}

Objetivo: Evaluar los efectos de la música sacra, instrumental y cantada en el bienestar espiritual de familiares enlutados. Método: Se trata de un ensayo clínico randomizado, realizado con familiares enlutados por la muerte, por cáncer, de entes queridos. Los participantes fueron distribuidos en tres grupos: Grupo 1 (control), Grupo 2 (experimental con música sacra cantada) o Grupo 3 (experimental con música sacra instrumental). El bienestar espiritual fue valorado mediante la Escala de Bienestar Espiritual. Resultados: Participaron 69 familiares. Los puntajes medios, antes y después de la intervención, señalaron altos niveles de bienestar espiritual (106,4 y 105,5 en el Grupo 1; 103,2 y 105,2 en el Grupo 2; 107,4 y 108,7 en el Grupo 3) y bienestar religioso (57,9 y 56,9 en el Grupo 1; 56,3 y 56,4 en el Grupo 2; 57,4 y 58,1 en el Grupo 3), y moderados niveles de bienestar existencial (48,5 y 48,6 en el Grupo 1; 46,9 y 48,9 en el Grupo 2; 49,9 y 50,7 en el Grupo 3), con excepción del Grupo 3, el que previa intervención presentó alto nivel. Conclusión: Los resultados demuestran que no hubo diferencia estadísticamente significativa en los puntajes de bienestar espiritual entre los grupos experimentales y el grupo control. Se evidencia la necesidad de nuevas investigaciones que utilicen la musicoterapia como intervención de Enfermería a la familia enlutada. Registro Brasileño de Ensayos Clínicos: RBR-2wtwjz.

\section{DESCRIPTORES}

Muerte; Pesar; Musica; Musicoterapia; Espiritualidad; Enfermería Holística.

\section{REFERENCES}

1. Bousso RS. The complexity and simplicity of the experience of grieving [editorial]. Acta Paul Enferm [Internet]. 2011 [cited 2017 Feb 02];24(3):ix. Available from: http://www.scielo.br/pdf/ape/v24n3/en_01.pdf

2. Bousso RS, Ramos D, Frizzo HCF, Santos MR, Bousso F. Facebook: um novo locus para a manifestação de uma perda significativa. Psicol USP [Internet]. 2014 [cited 2017 Feb 08];25(2):172-9. Available from: http://www.scielo.br/pdf/pusp/v25n2/0103-6564-pusp-25-02-0172.pdf

3. Caldeira S, Carvalho EC, Vieira M. Between spiritual wellbeing and spiritual distress: possible related factors in elderly patients with cancer. Rev Lat Am Enfermagem. [Internet]. 2014 [cited 2017 Feb 02];22(1):28-34. Available from: http://www.scielo.br/pdf/rlae/ v22n1/0104-1169-rlae-22-01-00028.pdf

4. Volcan SMA, Sousa PLR, Mari JJ, Horta BL. Relação entre bem-estar espiritual e transtornos psiquiátricos menores: estudo transversal. Rev Saúde Pública [Internet]. 2003 [citado 2017 fev. 02];37(4):440-5. Disponível em: http://www.scielo.br/pdf/rsp/v37n4/16778.pdf

5. Kimura M, Oliveira AL, Mishima LS, Underwood LG. Cultural adaptation and validation of the Underwood's Daily Spiritual Experience Scale - Brazilian version. Rev Esc Enferm USP [Internet]. 2012 [cited 2017 Feb 02];46(n.spe):99-106. Available from: http://www.scielo. br/pdf/reeusp/v46nspe/en_15.pdf

6. Bousso RS, Poles K, Serafim TS, Miranda MG. Religious beliefs, illness and death: family'sperspectives in illness experience. Rev Esc Enferm USP [Internet]. 2011 [cited 2017 Feb 02];45(2):391-7. Available from: http://www.scielo.br/pdf/reeusp/v45n2/en_v45n2a13.pdf

7. Pimenta CAM. Palliative care: a new specialty in profession of nursing? [editorial]. Acta Paul Enferm [Internet]. 2010 [cited 2017 Feb 02];23(3):ix. Available from: http://www.scielo.br/pdf/ape/v23n3/en_v23n3a01.pdf

8. Church Music Association of America. What is sacred music? [Internet]. 2017 [cited 2017 Feb 02]. Available from: http://musicasacra. com/about-cmaa/faq/

9. Cantz P. A psychodynamic inquiry into the spiritually evocative potential of music [abstract]. Int Forum Psychoanal [Internet]. 2013 [cited 2017 Feb 02];22(2):69-81. Available from: http://www.tandfonline.com/doi/abs/10.1080/0803706X.2012.657673

10. Goldman DP. Sacred music, sacred time. First Things [Internet]. 2009 [cited 2017 Feb 02]. Available from: https://www.firstthings.com/ article/2009/11/sacred-music-sacred-time

11. Almeida AP, Silva MJP. Canto Gregoriano: redutor de ansiedade de mães com filhos hospitalizados. Acta Paul Enferm [Internet]. 2012 [citado 2017 fev. 02];25(1):36-42. Disponível em: http://www.scielo.br/pdf/ape/v25n1/v25n1a07.pdf

12. Schulz KF, Altman DG, Moher D; CONSORT Group. CONSORT 2010 statement: updated guidelines for reporting parallel group randomised trials. BMJ [Internet]. 2010 [cited 2017 June 09];340:c332. Available from: https://www.ncbi.nlm.nih.gov/pmc/articles/PMC2844940/

13. Marques LF, Sarriera JC, Dell'Aglio DD. Adaptação e validação da escala de bem-estar espiritual (EBE). Aval Psicol [Internet]. 2009 [citado 2017 fev. 02];8(2):179-86. Disponível em: http://pepsic.bvsalud.org/pdf/avp/v8n2/v8n2a04.pdf

14. Robb SL, Burns DS, Carpenter JS. Reporting guidelines for music-based interventions. J Health Psychol. [Internet]. 2011 [cited 2017 Feb 02];16(2):342-52. Available from: https://www.ncbi.nlm.nih.gov/pmc/articles/PMC3141224/ 
15. Juslin PN, Lindström E. Musical expression of emotions: modelling listeners' judgments of composed and performed features. Music Analysis. 2010;29:334364.

16. Silva VA. Bem-estar espiritual decorrente da audição passiva de música sacra em familiares enlutados: ensaio clínico randomizado [tese doutorado]. São Paulo: Universidade de São Paulo, Escola de Enfermagem; 2015.

17. Iliya YA. Music therapy as grief therapy for adults with mental illness and complicated grief: a pilot study. Death Stud. 2015;39(1-5):173-84.

18. Magill L. The meaning of the music: the role of music in palliative care music therapy as perceived by bereaved caregivers of advanced cancer patients. Am J Hosp Palliat Care. 2009;26(1):33-9.

19. Silva VA, Sales CA. Musical meetings as a resource in oncologic palliative care for users of a support homes. Rev Esc Enferm USP [Internet]. 2013 [cited 2017 Feb 02]; 47(3):624-30. Available from: http://www.scielo.br/pdf/reeusp/v47n3/en_0080-6234-reeusp-47-3-00626.pdf

20. Silva VA, Marcon SS, Sales CA. Percepções de familiares de pessoas portadoras de câncer sobre encontros musicais durante o tratamento antineoplásico. Rev Bras Enferm [Internet]. 2014;67(3):408-14. [citado 2017 fev. 02]. Disponível em: http://www.scielo.br/pdf/reben/ v67n3/0034-7167-reben-67-03-0408.pdf

21. Luczinski GF, Ancona-Lopez, M. A psicologia fenomenológica e a filosofia de Buber: o encontro na clínica. Estudos Psicol [Internet]. 2010 [citado 2017 fev. 02];27(1):75-82. Disponível em: http://www.scielo.br/pdf/estpsi/v27n1/v27n1a09.pdf

22. Farinasso ALC, Labate RC. Luto, religiosidade e espiritualidade: um estudo clínico-qualitativo com viúvas idosas. Rev Eletr Enf [Internet]. 2012 [citado 2017 fev. 02];14(3):588-95. Disponível em: https://www.fen.ufg.br/fen_revista/v14/n3/pdf/v14n3a15.pdf 